\title{
COMPARATIVE CHARACTERIZATION OF SOMATIC HYBRIDS OF SOLANUM BULBOCASTANUM + S. TUBEROSUM CV. 'RASANT' WITH THEIR PARENTS IN RELATION TO BIOCHEMICAL RESPONSES TO WOUND STRESS AND TRICHOME COMPOSITION
}

\author{
DANIEL CRUCERIUa, IMOLA ERDELY-MOLNAR ${ }^{a}$, \\ ZORITA DIACONEASA ${ }^{\mathrm{b}}$, ANTONIA MARIA MARGINEANU ${ }^{\mathrm{a}}$, \\ ADRIANA AURORI ${ }^{\mathrm{a}, \mathrm{c}}$, ELENA RAKOSY-TICAN ${ }^{\mathrm{a}, *}$
}

\begin{abstract}
Potato production is severely affected worldwide due to its susceptibility to pathogens and pests. Solanum bulbocastanum, a potential source of resistance genes, is sexually incompatible with potato. Therefore, somatic hybridization is an alternative tool for enrichment of the potato resistance gene pool. Some important mechanisms involved in resistance are trichomes and various plant secondary metabolites. These resistance mechanisms were recorded in $S$. bulbocastanum, potato cv. 'Rasant' and two of their somatic hybrids with different chromosome numbers in order to evaluate the acquisition of these resistance traits by somatic hybridization. The foliar trichomes were characterized microscopically for morphology and density. Total polyphenolic (TPC) and flavonoid (TFC) content and antioxidant activity (AA) were quantified, both before and after mechanical wounding. Wounding increased TPC, TFC and AA in all tested genotypes. S. bulbocastanum was far superior for all parameters when compared with S. tuberosum cv. Rasant. The $1508 / 5$ somatic hybrid proved to be similar to the wild species for trichome morphology and density, whereas it has intermediate phenotype for the TPC, TFC and AA compared to the genitors. Therefore, somatic hybridization proves to be a useful tool for resistance mechanisms transfer from a wild species to a somatic hybrid, the 1508/5 genotype being a good candidate for future use in pre-breeding programs.
\end{abstract}

Keywords: antioxidant activity, cytogenetic, flavonoids, polyphenols, somatic hybrids, trichomes

a "Babes-Bolyai" University, Department of Molecular Biology and Biotechnology, 5-7 Clinicilor Street, Cluj-Napoca 400006, Romania

b University of Agricultural Sciences and Veterinary Medicine, Faculty of Food Science and Technology, 3-5 Calea Mănăştur, Cluj-Napoca 400372, Romania

c University of Agricultural Sciences and Veterinary Medicine, Advanced Horticultural Research Institute of Transylvania, 3-5 Calea Mănăștur, Cluj-Napoca 400372, Romania

${ }^{*}$ Corresponding author: Elena Rakosy-Tican, Email: rakosy.elena@gmail.com 
DANIEL CRUCERIU, IMOLA ERDELY-MOLNAR, ZORITA DIACONEASA,

ANTONIA MARIA MARGINEANU, ADRIANA AURORI, ELENA RAKOSY-TICAN

\section{INTRODUCTION}

Potato is an important food source for the world population, ranking fourth in terms of worldwide crop production, after wheat, corn and rice [1]. However, $S$. tuberosum is highly susceptible to a wide variety of pests and pathogens, like viruses [2], bacteria [3] or fungi [4].In this context, several wild potato species with broad resistance to biotic and abiotic stress factors were identified as reliable genetic resources for the potato gene pool enrichment [5]. One of such species is $S$. bulbocastanum, a wild diploid Mexican potato species, with accessions which retain resistance to a multiple pests and pathogens [6].

It is difficult to improve the cultivated potato species by classical breeding, due to its sexual incompatibility with most of the wild Solanum species, caused by differences in ploidy level and/or endosperm balanced numbers (EBN). Somatic hybridization, an alternative to classical breeding and transgenesis, is a biotechnological tool by which multiple resistance genes and derived mechanisms may be transferred between two distinct species by protoplasts fusion, protoplasts being isolated from each parent [5, 7-9].

Wild plants hold several different resistance mechanisms to each specific environmental factor. Among the structural features, an important defensive role is played by trichomes, specialized hairs found on the surface of vascular plants. Direct correlations between trichomes density and resistance to insects have been repeatedly reported $[10,11]$. Furthermore, there is evidence that glandular trichomes from Solanum species are involved in resistance to $P$. infestans [12]. Trichomes of the Solanaceae, intensively studied in tomato, are distinguished by eight different types, of which four are glandular and four are non-glandular [13]. However, potato and its somatic hybrids were less investigated in respect to their trichome types and densities [14].

Polyphenols are plant important secondary metabolites, which are known to be involved in plant responses to biotic and abiotic stresses. They take part in the non-enzymatic antioxidant system, with an important role in maintaining the redox state of the cell, due to their strong antioxidant capacity [15]. These compounds are found constitutively in plant tissues, their concentration being sometimes critical for an organism to be resistant to a specific pathogen $[16,17]$. Moreover, there is evidence that their concentration is rapidly increasing if a stress factor appears in the environment, further highlighting their relevant role in plant defense [18]. Polyphenol and flavonoid de novo synthesis is associated with both abiotic factors like strong light, wounding or exposure to UV light [19-21], and biotic stresses such as bacteria [22], insects [23] and other pathogens [24]. 
Physical wounding occurs in plants at each herbivore attack, process that stimulates polyphenol accumulation as a defense mechanism at the affected site. A recent report indicates that different polyphenols are synthesized when an insect starts consuming the plant [25]. Furthermore there is evidence proving that the accumulation of these secondary metabolites is related to mechanical wounding, even in the absence of herbivore feeding [26].

In this paper, we evaluate two previously obtained somatic hybrids between $S$. tuberosum cv. 'Rasant' and the wild species $S$. bulbocastanum [9], with the main goal to characterize their resistance mechanisms to several environmental factors in comparison with their parents. We determined the trichome morphology and density found on the surface of their leaves in order to assess the differences between genotypes from a physical defense mechanism perspective. Moreover, we evaluated the total phenolic content (TPC), total flavonoid content (TFC) and their antioxidant activity (AA) constitutively found in all genotypes and also after wounding, in order to determine both the differences among genotypes and their response to mechanical wounding. These data, correlated with the SHs chromosome number, reveal and confirm clear differences between the two somatic hybrids and highlight the role of analyzed secondary metabolites in wound stress.

\section{RESULTS AND DISCUSSION}

\section{Ploidy and chromosome counts results}

The indirect cytogenetic analysis based on the number of chloroplasts per guard cell proved to be a very simple and cost effective technique revealing the chromosome numbers with an error of \pm 2 chromosomes. Using the correlation curve and statistical analysis it was estimated that the $\mathrm{SH}$ $1508 / 5$ has 63.53 chromosomes, while chromosome counts revealed 62 chromosomes (Fig. 1). The SH 1508/2 has 71.26 chromosomes as indicated by indirect calculation as compared to 68 after direct chromosome counts (Fig. 1).

\section{Trichome morphology and density}

Trichome diversity was evaluated based on the classification established by Luckwill (1943) and updated by Channarayappa et al. (1992) according to whom, on Solanaceae leaves 8 different types of thricomes might exist $[13,27]$. The classification is based on morphological and physiological features like secretory capacity, basal cells number and morphology, dimension or glandular cells number. We identified 6 out of 8 possible trichome types 
DANIEL CRUCERIU, IMOLA ERDELY-MOLNAR, ZORITA DIACONEASA, ANTONIA MARIA MARGINEANU, ADRIANA AURORI, ELENA RAKOSY-TICAN

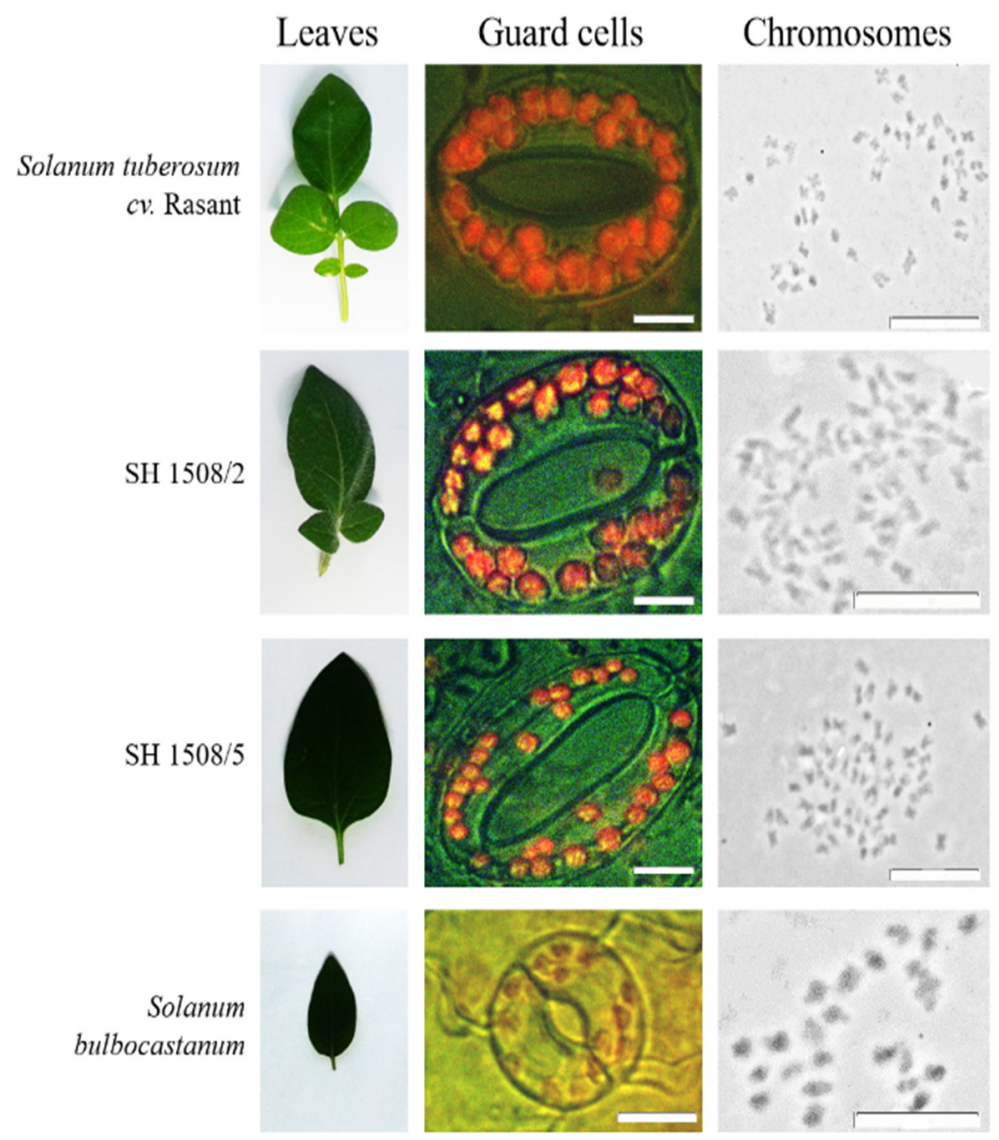

Figure 1. Comparative presentation of analyzed clones for leaf morphology, guard cells used for counting chloroplasts under epifluorescent microscopy (60X) and chromosome numbers (phase contrast pictures) (100X immersion). Bars: $10 \mu \mathrm{m}$

on the surfaces of our genotypes, but their diversity varies between genotypes (Fig. 2 and 3). Types II and III, part of the non-glandular subtype, and types $\mathrm{VI}$ and VII belonging to the glandular subtype were identified on all four analyzed genotypes. However, two additional types, IV (non-glandular) and $\mathrm{V}$ (glandular) were identified only on the leaves of $S$. bulbocastanum and the SH 1508/5 (Table 1). 

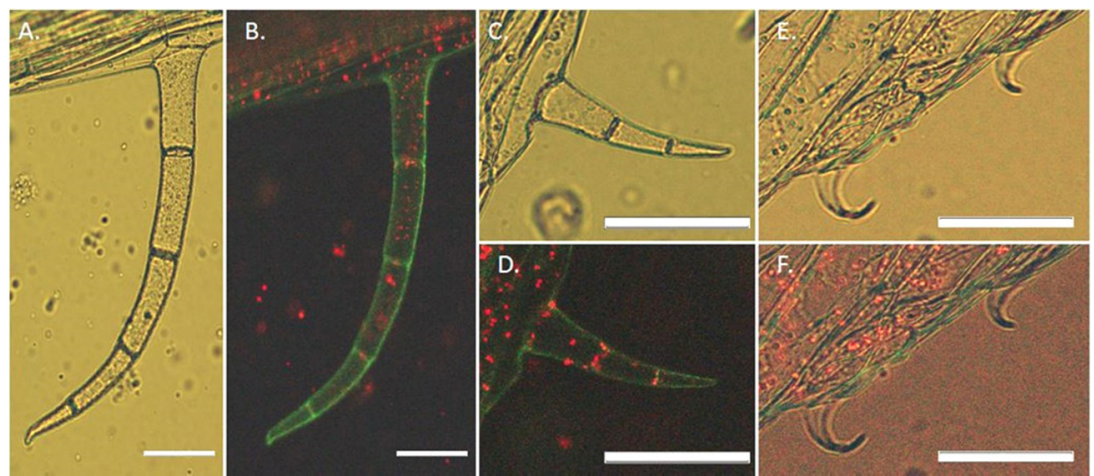

Figure 2. Non-glandular trichomes identified on the leaves of at least one genotype, under direct and UV light. Type II - under direct (A) and UV (B) light; Type III - under direct (C) and UV (D) light; Type V - under direct (E) and UV + direct (F) light. Note that Type $V$ does not have fluorescence under UV light. Red fluorescence is emitted by chlorophyll. Bars: $100 \mu \mathrm{m}$
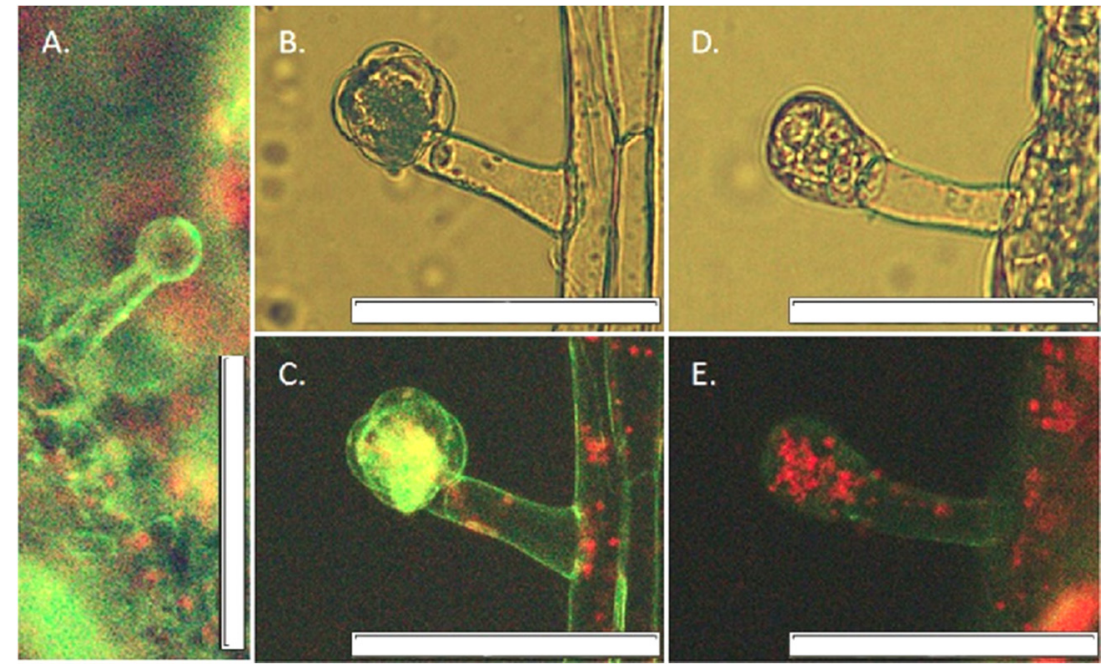

Figure 3. Glandular trichomes identified on the leaves of at least one genotype, under direct and UV light. Type IV - under UV light (A); Type VI, young trichome under direct (B) and UV (C) light; Type VII, mature trichome - under direct (D) and UV (E) light. Bars: $100 \mu \mathrm{m}$ 
Table 1. Distribution of trichome types among all four analyzed genotypes: $S$. bulbocastanum (S. blb), S. tuberosum cv. 'Rasant' and two somatic hybrids (1508/5 and 1508/2). "+" represents the presence of each specific type on the leaves.

\begin{tabular}{|c|c|c|c|c|c|c|}
\hline Genotype & Type II & Type III & Type IV & Type V & Type VI & Type VII \\
\hline S. blb & + & + & + & + & + & + \\
\hline 'Rasant' & + & + & & & + & + \\
\hline $1508 / 5$ & + & + & + & + & + & + \\
\hline $1508 / 2$ & + & + & & & + & + \\
\hline
\end{tabular}

In terms of native fluorescence under UV light, the non-glandular type II and III trichomes present red fluorescence inside the cells, showing chlorophyll content, and thus photosynthetic activity. On the other hand, type IV trichome does not show any kind of fluorescence. Regarding the glandular trichomes, all three types that were found on leaf surfaces presented either green or red fluorescence, or a combination of the two (Fig. 3).

Trichome densities determined for each genotype are presented in Fig. 4. The lowest total density is characteristic for $S$. tuberosum cv. Ransat, with only $340 \pm 16.7$ trichomes $/ \mathrm{cm}^{2}$, while the highest was found on the leaves of S. bulbocastanum $(598 \pm 17.5)$ and the SH 1508/5 $(620 \pm 15.3)$. The SH $1508 / 2$ presented intermediate phenotype (522 \pm 7.8$)$ when compared to the two parents. The major differences between genotypes occurs in the glandular trichome density, even though significant differences $(p<0.05)$ are also observed in the non-glandular hair density, when comparing the cultivated potato with all the other genotypes.

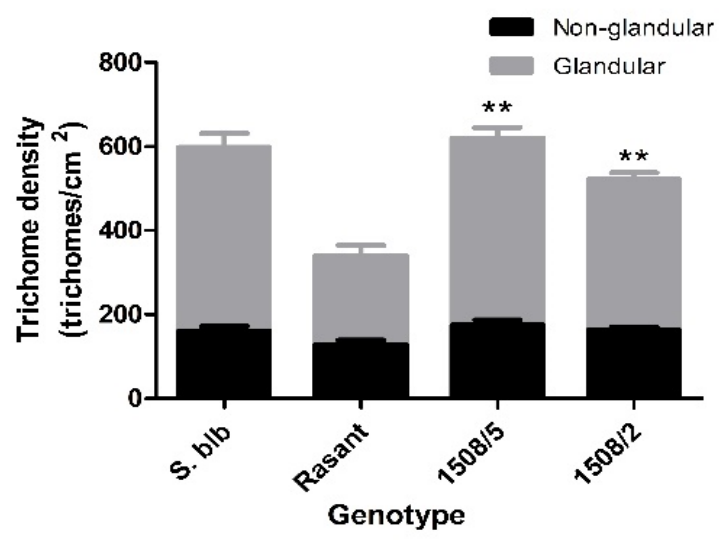

Figure 4. Non-glandular (black) and glandular (grey) trichome density for all four genotypes: S. bulbocastanum (S. blb), S. tuberosum cv. 'Rasant' (Rasant) and two somatic hybrids (1508/5 and 1508/2). For each somatic hybrid, ${ }^{* *}$ shows a highly significant difference $(p<0.01)$ in comparison to $S$. tuberosum $\mathrm{cv}$. 'Rasant' 
Non-glandular trichomes are directly involved in plant stress response, being implicated in specific resistance mechanisms to both biotic and abiotic factors. They reduce the insect's movement on leaf surfaces [28], are a mechanical barrier to pathogen attacks [29], participate in temperature and humidity regulation [30] and in calcium ions homeostasis [31]. Thus, the presence of an additional non-glandular type on the surface of $S$. bulbocastanum and the somatic hybrid $1508 / 5$ can be considered a morphological advantage, conferring resistance to all these environmental factors, when compared to the cultivar.

Glandular trichomes are known to secrete a vast variety of secondary metabolites, with implications in the physiological response to biotic stress factors. Type VI secrets different terpenoids [32], that are repellent or toxic for different parasites and insects, while type VII appears to synthesize protease inhibitors which affect the growth of insect larvae [33]. Type IV, the glandular type that was identified only on the leaves of the wild species and the 1508/5 somatic hybrid, is known to secrete sugar esters [33], which are toxic for the consuming insects [34]. In this context, S. bulbocastanum is superior in terms of resistance to consumers when compared to the cultivar. Furthermore, the 1508/5 somatic hybrid has presumably inherited the trichome diversity from the wild species, therefore it acquired novel resistance mechanisms in comparison with the cultivated potato.

Trichome density has an important contribution in regard to plant general resistance to environmental factors. Several reports demonstrate a correlation between hair density on leaves surface and resistance to different biotic stress factors [10,35]. Therefore, both somatic hybrids might possess greater resistance towards these stress factors because they acquired higher trichome densities through somatic hybridization.

\section{Total phenolic and flavonoid contents and the antioxidant activity}

The TPC and TFC for each genotype, both under control conditions and after wounding are presented in Fig. 5 (A.) and (B.) The highest constitutive phenolic and flavonoid contents (under control conditions) were found in S. bulbocastanum, while S. tuberosum cv. 'Rasant' and the SH 1508/2 proved to have low TPC and TFC. The SH 1508/5 has intermediate phenotype in regard to both physiological traits, when compared to the parents.

The results for the AA are presented in Fig. 5 (C.). Similar to our data on TPC and TFC, the highest AA was found in S. bulbocastanum and low antioxidant capacity was observed in the cultivar and the SH 1508/2. Furthermore, the $\mathrm{SH} 1508 / 5$ proved to be intermediate in regard to the AA, when compared with its parents. A strong correlation between TPC and AA was observed under both sets of conditions, the Pearson correlation coefficient being $0.995(p<0.01)$ in control plants. 
All three parameters increased after wounding, for all the genotypes tested. S. tuberosum cv. 'Rasant' has high increasing rates for both TPC and TFC after wounding, but these secondary metabolites are found in lower final concentration, in comparison with the SH 1508/5. Thus, the somatic hybrid is still superior in regard to these physiological traits. The observed increase in $A A$ after wounding is most probably caused by the accumulation of polyphenols and flavonoids, but also by other compounds with antioxidant capacity. This might explain the differences in the increasing rates observed for TPC on one hand and AA on the other hand.

A.

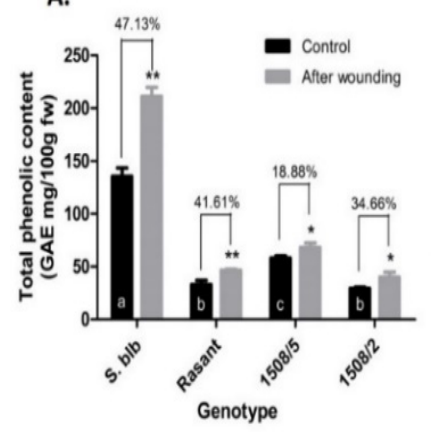

B.

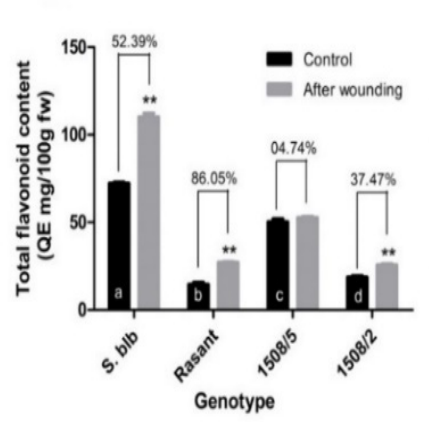

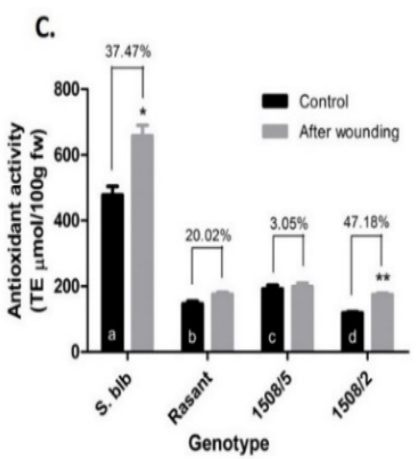

Figure 5. Total phenolic content (A.), total flavonoid content (B.) and Antioxidant activity (C.) under control conditions and after wounding, for all four analyzed genotypes: S. bulbocastanum (S. blb), S. tuberosum cv. 'Rasant' (Rasant) and two somatic hybrids (1508/5 and 1508/2). For each measurement after wounding, * shows a statistically significant difference at $p<0.05$ and ${ }^{* *}$ shows a highly significant difference at $p<0.01$ in TPC/ TFC/ AA when compared to control conditions. The increased rates (\%) for TPC/ TFC/ AA after wounding for each genotype are shown above each set of data. Significant differences $(p<0.05)$ between genotypes in control conditions are represented by different letters. Data are means $\pm S D(n=3)$

Phenols, including flavonoids, found constitutively in plant tissues, are involved in resistance mechanisms to a wide variety of biotic and abiotic factors. They act as protective molecules against UV light, strong light, heavy metals in soils, high/low temperature [18] but also against herbivores, especially insects, their constitutive concentrations being correlated with broad-spectrum resistance to environmental attacks [23]. Nevertheless, in Solanum species, flavonoids proved to be directly involved in resistance to $E$. carotovora and $P$. infestans [36]. Therefore, the $\mathrm{SH} 1508 / 5$ possesses relevant additional resistance features, due to its higher total phenolic and flavonoid content when compared to the cultivar. 
Several reports prove that wounding causes TPC and TFC increase, both after artificial and biotic damage [37, 38]. Furthermore, an increase in TPC and TFC was observed for Solanum species, after wounding, irradiation or infection with pathogens [39]. Our results are consistent with these data, for all four genotypes increases in TPC and TFC being observed after artificial mechanical wounding.

Polyphenols and implicitly flavonoids, are part of plant resistance mechanisms due to their toxicity, repellent action or their role as phytoalexins, but also because of their strong antioxidant activity [15]. One of the first physiological events that occur in plants after stress is the generation of reactive oxygen species (ROS), molecules which have a dual role [40]. First, they act as signaling molecules in initiating defense responses, but they are also toxic for the cell if their intracellular concentration increases beyond a threshold value $[17,41]$. In this context, polyphenols take part in maintaining the ROS intracellular concentration, due to their antioxidant capacity and thus are involved in plant stress responses. Our results demonstrate firstly that polyphenols are truly involved in the antioxidant activity of our genotypes, due to the strong correlation observed between TPC and AA. Furthermore, our data regarding the $A A$ suggest that $S$. bulbocastanum is far better in comparison with the cultivar and also that the SH 1508/5 inherited in part its antioxidant capacity from the wild species. Therefore, both genotypes present better adaptation mechanisms to environmental stress factors along with already demonstrated presence of two late blight resistance genes (Rpi-blb1 and Rpi-blb3 - Rakosy-Tican et al. under publication).

S. bulbocastanum proved to be superior in comparison with the cultivated potato in all studied aspects, having 2 additional trichome types, grater trichome density on its leaves and higher TPC, TFC and AA, both under control conditions and after wounding. We expected these results, S. bulbocastanum being resistant to different abiotic and biotic stress factors, like aphids, nematodes, or the oomycete Phytophthora infestans, while the cultivar is susceptible to these attacks. Thus, the wild species would presumably have multiple resistance mechanisms towards these environmental factors, assumption also demonstrated by our results on trichomes and some physiological responses to artificial wounding (this study) or the stress caused by in vitro culture [21].

The SH 1508/5 proved to be superior in regard to all studied morphological/physiological traits when compared with its cultivated genitor although it possessed fewer chromosomes than SH 1508/2. It is similar with the wild species when it comes to trichome diversity and density, and has intermediate TPC, TFC and AA under both sets of conditions tested in this study. This genotype previously proved to be resistant to late blight, due to the presence in its genome of two genes (Rpi-blb1 and Rpi-blb3) that are known to be directly involved in the gene-for-gene durable resistance mechanism to the pathogen 
DANIEL CRUCERIU, IMOLA ERDELY-MOLNAR, ZORITA DIACONEASA,

ANTONIA MARIA MARGINEANU, ADRIANA AURORI, ELENA RAKOSY-TICAN

(Rakosy-Tican et al. under publication). Correlating these results, the SH 1508/5 is a good candidate for future pre-breeding programs, due to the acquisition of multiple resistance traits/ mechanisms through somatic hybridization.

\section{EXPERIMENTAL SECTION}

\section{Plant material}

In this study we analyzed four different genotypes of Solanum: the wild diploid Mexican potato species S. bulbocastanum GLKS-31741 [blb41; Gross Lüsewitz Potato Collections (GLKS) of the IPK Gene Bank, LeibnizInstitute of Plant Genetics and Crop Plant Research, Germany]; a commercial potato cultivar, S. tuberosum cv. 'Rasant' (Nordring-Kartoffelzucht-und Vermehrungs-GmbH Gross Lüsewitz, Germany); and two asymmetric somatic hybrids - $1508 / 5$ and $1508 / 2$, produced by mesophyll protoplast electrofusion [9]. The starting material was represented by micro-tubers maintained in vitro on MS medium [42], with $10 \%$ sucrose at $4{ }^{\circ} \mathrm{C}$. All four genotypes were cultivated in vitro for four weeks under controlled conditions $\left(25{ }^{\circ} \mathrm{C} \pm 2{ }^{\circ} \mathrm{C}\right.$, photoperiod $16 \mathrm{~h} / 8 \mathrm{~h}$ day/night, $60 \%$ humidity and a light intensity of $135 \mu \mathrm{mol} \mathrm{m} \mathrm{m}^{-2} \mathrm{~s}^{-1}$ ) and acclimatized subsequently under ex vitro conditions, in soil. They were cultured under uncontrolled environmental conditions (room temperature: $24^{\circ} \mathrm{C} \pm 3{ }^{\circ} \mathrm{C}$, photoperiod: approximately $12 \mathrm{~h}$, in sunlight during May), for eight weeks.

The hybridity of our somatic hybrids (SHs) was previously demonstrated through flow-cytometry while the use of SSR and AFLP markers proved their asymmetric status [9]. From a morphologic perspective, the somatic hybrids have intermediate phenotype when compared to the parents, both in regard to their biomass, plant height and leaf morphology (Fig. 1). They present intermediate leaf morphology, with the $1508 / 5$ hybrid being more similar to the cultivated genitor and the 1508/2 genotype more likened with the wild species (Fig. 1) [21]. An extremely relevant aspect is that the $1508 / 5$ somatic hybrid proved to be resistant to $P$. infestans in detached leaf assay and field assessments. Furthermore, its genome contains two genes (Rpi-blb1 and Rpiblb3) directly involved in the gene-to-gene durable resistance mechanism to late blight (Thieme R. personal communication) (Table 2).

Although flow cytometry data reveal that the two somatic hybrids used in this study are pentaploids, indirect and direct cytogenetic methods were applied to better characterize their genetic composition. As indirect method counting of chloroplasts per guard cell was applied. Three leaves from three individual plants for each genotype (parents and SHs) were harvested from three weeks old in vitro plants. The abaxial epidermis was peeled out and three different microscopic fields were randomly selected to count the chloroplasts 
in each guard cell using epifluorescent microscopy (Olympus BX-60 objective 60X). The chlorophyll auto-fluorescence facilitated the counting of the chloroplasts per 54 guard cells per analyzed genotype (Fig. 1). The mean number of chloroplasts per guard cell was used to calculate the number of chromosomes based on the correlation curve obtained for the parental genotypes with known ploidy level, Solanum bulbocastanum $2 x=24$ diploid and S. tuberosum cv. 'Rasant' $2 x=48$, tetraploid.

Table 2. Available data on the parents and somatic hybrids (SH) used in the present study: hybrid nature was confirmed by SSR markers and flow cytometry; resistance to late blight caused by oomycete Phytophthora infestans $(\mathrm{Pi})$ was evaluated in detached leaf assays (DLA) and noted using a scale 1 for the most resistant and 9 for the most susceptible; two Rpi genes were followed by using specific molecular markers (data under publication)* For details on SSR markers see Rakosy-Tican et al. (2015)

\begin{tabular}{|c|c|c|c|c|}
\hline Genotype & $\begin{array}{l}\text { Hybridity/ molecular } \\
\text { markers }\end{array}$ & Ploidy & $\begin{array}{c}\text { Resistance to } \\
\text { Pi - DLA }\end{array}$ & Rpi genes \\
\hline $\begin{array}{l}\text { S. bulbocastanum } \\
\text { blb41 }\end{array}$ & - & $2 x$ & Yes/ 1 & $\begin{array}{l}\text { Rpi-blb1 } \\
\text { Rpi-blb3 }\end{array}$ \\
\hline $\begin{array}{l}\text { S. tuberosum cv. } \\
\text { Rasant }\end{array}$ & - & $4 x$ & No/ 5.35 & none \\
\hline SH 1508/2 & $\begin{array}{l}\text { Yes/SSR STIIKA, } \\
\text { STM2022* }\end{array}$ & $5 x$ & ND & ND \\
\hline SH 1508/5 & $\begin{array}{l}\text { Yes/SSR STIIKA, } \\
\text { STM2022** }\end{array}$ & $5 x$ & Yes/ 2 & $\begin{array}{l}\text { Rpi-blb1 } \\
\text { Rpi-blb3 } \\
\end{array}$ \\
\hline
\end{tabular}

\section{Characterization of ploidy and chromosome numbers by using indirect and direct cytological tools}

For direct chromosome counts root meristem was used. The roots were induced on nodal segments ( $n=20$ per genotype) cultured in vitro on MS medium with $0.05 \mathrm{mg} \mathrm{L}^{-1} \mathrm{NAA}$ ( $\alpha$-naftalene acetic acid) pH 5.8. Roots, $10 \mathrm{~mm}$ long were harvested and maintained on ice overnight. Then the roots were fixed in ethanol:acetic acid $1: 3$ for $24 \mathrm{~h}$ and maintained at $-20^{\circ} \mathrm{C}$ until use. The fixed roots were transferred to citrate buffer for $25 \mathrm{~min}$ at room temperature. The roots were digested with enzyme solution made up of $0.4 \%$ pectolyase, $0.4 \%$ citohelycase and $1 \%$ celullase in citrate buffer $\mathrm{pH} 4.8$. Enzymatic digestion was performed at $37^{\circ} \mathrm{C}$ for $30 \mathrm{~min}$. The roots were washed with citrate buffer for $20 \mathrm{~min}$ at $4{ }^{\circ} \mathrm{C}$. Then the root tips containing the meristem were dissected under stereomicroscope with entomological needles. The slides were fixed with a flame and the chromosomes were counted under the microscope using phase contrast microscopy (microscope Olympus BX-60, objective 100X). 
DANIEL CRUCERIU, IMOLA ERDELY-MOLNAR, ZORITA DIACONEASA,

ANTONIA MARIA MARGINEANU, ADRIANA AURORI, ELENA RAKOSY-TICAN

\section{Trichome analysis}

Trichome type: for each genotype, six fully expanded leaves with mature trichomes originating from two individuals were considered for the trichome morphological analysis. Epidermis from the leaf abaxial surface was peeled out and analyzed through optical microscopy (Olympus BX60), with the 10X objective, under direct light. Simultaneously, the trichomes were analyzed under UV light (filter cube: excitation filter at 450-480 nm, dichroic mirror at $500 \mathrm{~nm}$, barrier filter at $515 \mathrm{~nm}$ ), in order to highlight their content in bioactive molecules. Images were taken using the Olympus CX50 CCD camera and CellSense software. The morphological analysis was based on the latest Solanaceae trichome classification presented by Channarayappa et al. (1992) according to which eight different trichome types might be present on potato leaves surfaces [13].

Trichome density was determined based on the analysis of the third and fourth leaves down from apex, originating from 3 different individuals for each genotype. Detached leaves were maintained in $70 \%$ ethanol, in the dark, at room temperature, for three weeks to remove the chlorophyll. Three randomly selected microscopic fields on the abaxial epidermis of each leaf, one at the leaf tip and two on each side were analyzed through stereomicroscopy and pictures were taken with digital camera (Olympus 5060). Trichome density was determined using Photoshop counting tools.

\section{Wounding procedure}

For each genotype, two leaves from three different individuals were taken into consideration for this procedure. All individuals were cultivated in the same environmental conditions as unwounded plants. The leaves were incised using scissors, $30 \%$ of each leaf being removed. After $16 \mathrm{~h}$, wounded leaves were detached and sample extraction was performed.

\section{Sample extraction}

For sample extraction, for both wounded and control plants, $1 \mathrm{~g}$ of leaf material derived from three different individuals was milled for each genotype, transferred in $10 \mathrm{~mL}$ extraction buffer [acidified methanol - 85:15 $\mathrm{v} / \mathrm{v}, \mathrm{MeOH}: \mathrm{HCl}$ ) [43] and incubated in the dark, at room temperature for 24 $\mathrm{h}$. The supernatant was collected after centrifugation and the residual tissue was re-extracted under stirring, through repeated extraction buffer addition, centrifugation and collection, until the extraction solvent became colorless [44]. The total extracts for all samples were dried using a vacuum rotary evaporator (Heidolph Laborota 4000 Efficient), at $40{ }^{\circ} \mathrm{C}$ and re-dissolved in $2 \mathrm{~mL}$ extraction buffer, prior to further analysis. 


\section{Total phenolic and flavonoid content determination}

Total phenolic content, for each sample, was determined using the colorimetric Folin-Ciocalteu method [45]. Samples of $25 \mu \mathrm{L}$ were mixed with $1.8 \mathrm{~mL}$ distilled water and $120 \mu \mathrm{L}$ Folin-Ciocalteu Reagent (FCR) for oxidation, and further neutralization was performed using $340 \mu \mathrm{L} \mathrm{Na} \mathrm{NO}_{3}$. After incubation $90 \mathrm{~min}$ in the dark, sample absorbance was measured at $750 \mathrm{~nm}$ through spectrophotometry (BioTek Instruments, Winooski, VT). The results were expressed as $\mathrm{mg}$ of gallic acid $100 \mathrm{~g}^{-1}$ of fresh weight (FW). All measurements were performed in triplicate.

The total flavonoid content was evaluated for each sample based on the colorimetric method elaborated by $\mathrm{Kim}$ et al. (2003) [46]. Aliquots containing $300 \mu \mathrm{L}$ of the alcoholic extracts were diluted in $1.2 \mathrm{~mL}$ distilled water and $90 \mu \mathrm{l} 5 \% \mathrm{NaNO}_{2}$ was added. After that, $90 \mu \mathrm{L} 10 \% \mathrm{AlCl}_{3}$ was added, the mixtures were allowed to stay for 6 min and $600 \mu \mathrm{L} 1 \mathrm{~N} \mathrm{NaOH}$ was added to each sample. The absorbance was measured at $510 \mathrm{~nm}$ through spectrophotometry (JASCO V-630 series, International Co.). All measurements were performed in triplicate and the results were expressed as $\mathrm{mg}$ quercetin equivalents $/ 100 \mathrm{~g}^{-1} \mathrm{FW}$.

\section{Antioxidant activity determination}

The antioxidant capacity was determined through the ABTS assay (ABTS radical cation distaining assay), based on the capacity of the samples to scavenge ABTS radicals, in comparison with Trolox, a standard antioxidant [47]. The $\mathrm{ABTS}^{+}$solution was prepared $16 \mathrm{~h}$ before the experiment, by mixing $7 \mathrm{mM}$ ABTS with $2.45 \mathrm{mM}$ potassium persulfate in the dark, being diluted afterwards with $70 \%$ ethanol, until the solution absorbance at $734 \mathrm{~nm}$ reached 0.7. Aliquots containing $20 \mu \mathrm{L}$ of each sample extract and Trolox were added in $170 \mu \mathrm{L} \mathrm{ABTS}{ }^{+}$solution and left in the dark, at $30{ }^{\circ} \mathrm{C}$, for $6 \mathrm{~min}$. The absorbance was measured at $734 \mathrm{~nm}$ on a 96 well microplate, through spectrophotometric means (BioTek Instruments, Winooski, VT). The results were expressed as $\mu$ mole Trolox equivalents $/ 100 \mathrm{~g}^{-1} \mathrm{FW}$ and for each genotype 3 measurements were performed.

\section{Statistical analysis}

Data shown in Fig. 1 are expressed as means \pm standard deviation of six different counts for each genotype, for both glandular and nonglandular trichomes. Unpaired tow-tailed t-tests were performed to determine if the difference between the trichome density on somatic hybrids leaves and the one on the parent's leaves is statistically significant. 
Unpaired two-tailed t-tests were also performed to establish the differences between genotypes in regard with their phenolic content, flavonoid content and antioxidant activity, under control conditions. Furthermore, the same statistical analysis was used to assess the disparity in TPC, TFC and AA before and after wounding, for each genotype. Pearson correlation test was used to assess the relationship between TFC and AA. The increase rate of TPC, TFC and AA (parameter) presented by each genotype after wounding, was calculated as follows:

$$
\text { Increased rate }(\%)=\left[\left(\frac{\text { parameter in control }}{\text { parameter after wounding }}\right)-1\right] \times 100
$$

All statistical analyzes were performed using the GraphPad Prism software (Graph Pad Software Inc; San Diego, CA, USA). Significance of difference was defined at the $5 \%$ level $(p<0.05)$ for all the t-tests used in this study. Before each statistical analysis, our data were tested for their variances using the F-test.

\section{CONCLUSIONS}

Somatic hybridization proves to be a useful biotechnological tool for resistance mechanisms transfer from a wild species to a somatic hybrid. It overcomes the pre- and post-zygote incompatibility barriers, while its major advantage is the transfer of multiple genes, as it happened with the SH 1508/5. The drawback of somatic hybridization is uncontrollable transfer of different numbers of chromosomes from the wild species - as it is the case of the two $\mathrm{SHs}$ analyzed here, but this can be resolved by thorough characterization of resulted somatic hybrid clones. Plant genetic transformation is not always a viable method, taking into consideration that the transfer of only a few genes doesn't guarantee the acquisition of the targeted resistance mechanisms. This study highlights the usefulness of somatic hybridization in transferring multiple resistance mechanisms into potato gene pool.

\section{ACKNOWLEDGEMENTS}

Authors are grateful to Dr Ramona Thieme, Dr. Olga Antonova and Dr. Marion Nachtigall for previous contribution to the characterization of somatic hybrids used in this paper. This research received no specific grant from any funding agency in the public, commercial, or not-for-profit sectors. 


\section{REFERENCES}

1. A.J. Haverkort; P.C. Struik; R.G.F. Visser; E. Jacobsen; Potato Res, 2009, 52, 249-264

2. L.F. Salazar; Potato viruses after the XXth century: effects, dissemination and their control; Crop Protection Department, Lima 12, Peru, 2003

3. J. Elphinstone; I. Toth; Erwinia chrysanthemi (Dickeya spp.): The Facts; British Pototo Council Publications, 2007

4. G.A. Forbes; W. Pérez; J. Andrade-Piedra; Field assessment of resistance in potato to Phytophthora infestans; International Center of Potato 2014

5. R. Thieme; E. Rakosy-Tican; Somatic Cell Genetics and Its Application in Potato Breeding. In The Potato Genome; S.K. Chakrabarti, C. Xie and J.K. Tiwari Eds.; Springer International Publishing AG Cham, Switzerland, 2017, pp. 217-269

6. D. Carputo; D. Alioto; R. Aversano; R. Garramone; V. Miraglia; C. Villano; L. Frusciante; Plant Genet. Resour., 2013, 11, 131-139

7. R. Thieme; E. Rakosy-Tican; T. Gavrilenko; O. Antonova; J. Schubert; M. Nachtigall; U. Heimbach; T. Thieme; Theor. Appl. Genet., 2008, 116, 691-700

8. R. Thieme; E. Rakosy-Tican; M. Nachtigall; J. Schubert; T. Hammann; O. Antonova; T. Gavrilenko; U. Heimbach; T. Thieme; Plant Cell Rep., 2010, 29,

9. E. Rakosy-Tican; R. Thieme; M. Nachtigall; I. Molnar; T. E. Denes; Plant Cell. Tiss. Org. Cult., 2015, 122, 395-407

10. G.G. Kennedy; Annu. Rev. Entomol., 2003, 48, 51-72

11. A.T. Simmons; G. M. Gurr; D. McGrath; P. M. Martin; H. I. Nicol; Aust. J. Entomol., 2004, 43, 196-200

12. A. Lai; V. Cianciolo; I. Chiavarini; A. Sonnino; Euphytica, 2000, 114, 165-174

13. S.G. Channarayappa; V. Muniyappa; R. H. Frist; Can J Bot, 1992, 70, 21842192

14. A.M. Mărgineanu; I. Erdelyi-Molnár; E. Rákosy-Tican; Analele Ştiinţifice ale Universităţii „Al. I. Cuza” laşi s. II a. Biologie vegetală, 2014, 60, 33-42

15. O. Blockhina; E. Virolainen; KV. Fagerstedt; Ann. Bot., 2002, 91, 179-194

16. K.K. Mallikarjuna N, Jadhav DR, Kranthi S, Chandra S J. App. Entomol., 2004, 128, 321-328

17. C.H. Foyer; B. Rasool; J.W. Davey; R.D. Hancock; J. Exp. Bot., 2016, 67, 20252037

18. J. Mierziack; K. Kostyn; A. Kulma; Molecules, 2014, 19, 16240-16265

19. G. Guillet; V. De Luca; Plant Physiol., 2005, 137, 692-699

20. M. Sisa; S.L. Bonnet; D. Ferreira; J.H. Van der Westhuizen; Molecules, 2010, 15, 5196-5245

21. D. Cruceriu; I. Molnar; Z. Diaconeasa; A. Aurori; C. Socaciu; E. Rakosy-Tican; Notulae Botanicae Horti Agrobotanici, 2017, 45, 75-81 


\section{DANIEL CRUCERIU, IMOLA ERDELY-MOLNAR, ZORITA DIACONEASA, ANTONIA MARIA MARGINEANU, ADRIANA AURORI, ELENA RAKOSY-TICAN}

22. J.S. Lorenc-Kukula K, Oszmianski J, Szopa, J. Agric. Food. Chem., 2005, 53, 272-281

23. D. Treutter; Environ. Chem. Lett., 2006, 4, 147-157

24. I. Yedidia; M. Shoresh; Z. Kerem; N. Benhamou; Y. Kapulnik; I. Chet; Appl. Environ. Microbiol., 2003, 69, 7343-7353

25. G.S. Nuessly; B.T. Scully; M.G. Hentz; R. Beiriger; M.E. Snook; N.W. Widstrom; J. Econ. Entomol., 2007, 100, 1887-1895

26. L.F. Reyes; L. Cisneros-Zevallos; J. Agric. Food. Chem., 2003, 51, 5296-5300

27. L.C. Luckwill; Aberd. Univ. Stud., 1943, 120, 1-44

28. H.B. Johnson; Bot. Rev., 1975, 41, 233-253

29. G.A. Beattie; S.E. Lindow; Phytopathology, 1999, 89, 353-359

30. J. Ehleringer; Ecology and ecophysiology of leaf pubescence in North American desert plants. In Biology and chemistry of plant trichomes; E. Rodriguez, P.L. Healey and I. Mehta Eds.; Plenum Press, New York, 1984, pp. 113-132

31. D.L. De Silva; T.A. Mansfield; M.R. McAinsh; Planta, 2001, 214, 158-162

32. A.L. Schilmiller; I. Schauvinhold; M. Larson; R. Xu; A.L. Charbonneau; A. Schmidt; C. Wilkerson; R.L. Last; E. Pichersky; Proc. Natl. Acad. Sci. U.S.A., 2009, 106, 10865-10870

33. E.T. McDowell; J. Kapteyn; A. Schmidt; C. Li; J.H. Kang; A. Descour; F. Shi; M. Larson; A. Schilmiller; L. An; A.D. Jones; E. Pichersky; C.A. Soderlund; D.R. Gang; Plant Physiol., 2011, 155, 524-539

34. G.J. Wagner; E. Wang; R. W. Shepherd; Ann. Bot., 2004, 93, 3-11

35. G.G. Simmons AT; Agric. Forest. Entomol., 2005, 7, 265-276

36. A. Kumar; V.S. Pundhir; Potato Res., 1991, 34, 9-16

37. S. E. Hartley; R.D. Firn; J. Chem. Ecol., 1989, 15, 275-283

38. H.M. Kang; M.E. Saltveit; J. Agric. Food. Chem., 2002, 50, 7536-7541

39. C.E. Lewis; J.R.L. Walker; J.E. Lancaster; K.H. Sutton; J. Sci. Food. Agric., 1998, 77, 58-63

40. G.R. Cramer; K. Urano; S. Delrot; M. Pezzotti; K. Shinozaki; BMC Plant Biol., 2011, 11, 163

41. C.H. Foyer; G. Noctor; Plant Cell., 2005, 17, 1866-1875

42. T. Murashige; F. Skoog; Physiologia Plantarum, 1962, 15, 473-497

43. M.A.A. El-Sayed; P. Hucl; J. Agric. Food Chem., 2003, 51, 2174-2180

44. A. Bunea; D.O. Dugină; A.M. Pintea; Z. Sconta; C.I. Bunea; C. Socaciu; Not. Bot. Horti. Agrobo., 2011, 39, 70-76

45. V.L. Singleton; R. Orthofer; R.M. Lamuela-Raventós; P. Lester; Method. Enzymol., 1999, 299, 152-178

46. D.O. Kim; S.W. Jeong; C.Y. Lee; Food Chem., 2003, 81, 321-326

47. M.B. Arnao; A. Cano; J.F. Alcolea; M. Acosta; Phytochem. Anal., 2001, 12, 138143 